The Pragmatic Motifs of the Jespersen Cycle: Default, Activation, and the History of Negation in French

\begin{abstract}
The purpose of this article is to delimit the role of pragmatic specialisation in the evolution of negation in French. The change in the marking of sentential negation is believed to proceed in characterised stages that would together constitute the Jespersen cycle. As a marker becomes the default expression of negation, the other markers do not necessarily fade away, and are maintained with specialised roles that include pragmatic functions. One such pragmatic function is that of activation (Dryer 1996), by which a proposition is presented as accessible to the hearer. Activation is shown to motivate the use of preverbal non that competes with ne for several centuries. The claims that the emergence of postverbal pas in early French and the loss of ne in contemporary spoken French are associated with activation are considered on the basis of novel data. It is concluded that pragmatic functions contribute to language change by providing marked options that may be confered the default status in a grammatical paradigm.
\end{abstract}

\title{
Keywords
}

Negation, Jespersen cycle, default, markedness, pragmatic activation, French. 


\section{The Pragmatic Motifs of the Jespersen Cycle: Default, Activation, and the History of Negation in French}

\section{Introduction}

Since Jespersen $(1917)^{1}$, the grammar of negation has been assumed to evolve following a cycle of successive stages. The expression of negation goes from a preverbal marker, to the preverbal marker plus a postverbal item, to the postverbal item alone. Well attested across languages, these three $^{2}$ successive stages $^{3}$ are generally illustrated by the following constructed realisation of I don't say in Old, Classical and Contemporary French:

Jeo ne dis

I NEG say

(2) Je ne dis pas

I NEG say NEG

(3)

Je dis pas

I say NEG

This raises two major questions:

1. Why should stages in the marking of negation emerge and decline?

2. Why should these successive stages form a cycle?

\footnotetext{
${ }^{1}$ The attribution to Jespersen is made by Dahl (1979), but Meillet (1912) or Gardiner (1904) might equally well have been credited, as noted by van der Auwera (2008: 6).

${ }^{2}$ See van der Auwera (2008) on different ways of counting (sub)stages.

${ }^{3}$ which may be completed by the postverbal marker appearing before the verb, as is the case in French-based creoles (Larrivée 2004: 19).
} 
This article primarily concerns the first question. The answer that is generally provided is that the emergence of new markers is motivated by pragmatic functions. The emergence of the stage 2 negative would be motivated by emphasis that would subside with increased frequency of usage (Detges and Waltereit 2002, Eckardt 2006, Hopper and Traugott 2003, Kiparsky and Condoravdi 2006, to cite only the principal recent studies). This is examined in the present article from three perspectives, concerning the status of emphasis and the alternative pragmatic notion of activation (Schwenter 2006), the purported causality of frequency, and the contribution of pragmatics to the relation between marked and default expressions in grammatical change. Issues arise as to the pragmatic notion of emphasis that is often used as a blanket characterisation not clearly related to empirical realisations, and as to whether a better characterisation can be offered by activation. The idea that change in the pragmatic status of a marked expression is brought about by usage frequency variation rather than reanalysis leads to the question of what causes the frequency variation in the first place, and whether this variation is sufficient to lead to the emergence of a new default marker or the decline of an existing marked expression. This brings to the fore the relation between a default expression and its marked alternatives in a grammatical paradigm as a precondition for grammatical change.

The current work has two aims. The first is to adjudicate the thesis that marked expressions of negation are sustained by specialised functions among which pragmatic values are found. The intervention of the pragmatic value of activation is put to the test on the basis of new data. The second one is to document the assumption that changes of stage in the Jespersen cycle are related to changes in the default negative, and that the identity of the default negative defines a stage. The changeable status of items as default or marked in 
grammatical paradigms is hence a general condition of language change (and plausibly variation). The subtext is that the value of emphasis, the causality of frequency and the view that seeks to marginalise marked options are problematic because they are unclear or unfactual. One thing that this work does not do is to propose an exploration of the critical moments of change, when pragmatic value is gained or lost or when an expression is reanalysed as default or marked, as such a contribution would go well beyond the scope of the current work, which nonetheless offers speculations on the matter in the conclusion. In addition to providing a general contribution to the understanding of variation and change through the relations between default and marked expressions in a grammatical paradigm, my objective is to present an empirically motivated picture of the role of pragmatic activation in the emergence and decline of expressions shaping the Jespersen cycle in French, by showing on the basis of novel data when activation can plausibly be said to intervene and when it cannot. This allows speculations to be made as to the reasons why the successive stages of default negation form a cycle.

These objectives are pursued as follows. The pragmatic value of negatives is examined in the opening section. It considers emphasis, and whether the facts that this label is applied to would be better characterised as activation in the sense of Dryer (1996) and Schwenter $(2005,2006)$. A pragmatically activated value is one way in which an emerging or declining expression can be marked in its discrete opposition to the default representative of the grammatical paradigm: change in a paradigm is driven by reanalysis rather than gradual increasing or decreasing usage, and reanalysis of a marker as default is what defines a stage in the cycle. The sections that follow consider expressions marked by an activated value on the basis of novel data. It is shown that the decline of preverbal non is associated with a pragmatically activated value in that its distribution is restricted to activated propositions. 
The claim that activated contexts promote the emergence of the postverbal adverb pas is evaluated by reference to new data closer to everyday Old French usage than literary texts might be. Existing corpora of contemporary conversational French allow for an assessment of whether declining ne is similarly associated with a pragmatic contribution. How these come to form a cycle is speculated upon in the conclusion. The argument is, in summary, that grammatical change should be conceived of as a competition between default and marked forms, and that marked negatives may have an activated value.

\section{Changes of grammatical state}

The historical grammar of negation has been largely viewed in terms of weakening and strengthening. This perspective has been applied to the well-documented evolution of literary French. Preverbal ne that is the preferred early French sentence negation is formally wearing out: it is a clitic, agglutinates to some vowel-initial clitics and verbs, having no prosodic and syntactic autonomy of its $\mathrm{own}^{4}$. This state of affairs may threaten the clear perception of negation ${ }^{5}$. Clarity as to the polarity of the sentence is brought by the formal intervention of a postverbal minimiser that has an affinity with negative contexts. Minimal measure is expressed in the first instance by items such as pas, point and mie in conjunction with lexically relevant verbs; ne marcher pas would have meant 'not to walk by even so much

\footnotetext{
${ }^{4}$ Semiological weakening does not always initiate the Jespersen cycle, as evidenced by Greek (Kiparsky and Condoravdi 2006) and Arabic (Lucas 2007). The lack of autonomy of French ne can however hardly be challenged, and this can be usefully contrasted to similar preverbal markers in Slavic languages which have mobility and prosodic independence (David Willis, personal communication). This in my view is a plausible reason why Slavic languages have not got to stage 2 of the Jespersen cycle.

${ }^{5}$ As is illustrated by the impossibility of establishing whether ne has been dropped in some contemporary French contexts when a vowel-initial verb is preceded by a clitic ending in /n/ such as on or en (see among many others Meisenberg 2004, Rowlett 1998: 169, ft 1).
} 
as a step'. The restriction to negative polarity environments ${ }^{6}$ may be accompanied by use with an extended set of verbs ${ }^{7}$ where no reference is made to the meaning of the original noun, as observed by Meillet (1912). From this, the postverbal items develop into negatives ${ }^{8}$. The embracing negation is initially pragmatically marked. Its contribution would correspond to emphasis whether pas qualifies as a negative polarity item, which has widening and strengthening values (Kadmon and Landman 1993), or a negative proper. Emphasis would be lost with the increased frequency of usage of embracing negation that would in time transform it into the standard negative expression.

Thus, syntagmatic reinforcement would give way to emphatic negation that increased frequency would reduce to a standard negative. This opposition between the emphatic and the neutral negatives proposed by Kiparsky and Condoravdi (2006) can be related to generic communicative requirements of production and perception: a speaker might want to make her position very clear with respect to whether a state of affairs obtains or not, and the hearer might gradually attribute less weight to a frequent structure; this tallies with the dual tension of Larry Horn's neogricean pragmatic theory (Horn 1984 and 1993 among other publications).

This story leaves some questions unanswered, with respect to the nature of the pragmatic notion, to its extension to all elements of the cycle and to the causal role attributed to frequency.

\footnotetext{
${ }^{6}$ Demonstrated by the use of pas without ne in interrogatives (Price 1993, Martineau and Vinet 2004).

${ }^{7}$ This was the case for pas and point, but not for goutte for instance, which remains essentially tied to ne voir goutte 'to see not a drop', "nothing at all".

${ }^{8}$ This supposes that the polarity item is used with sentence negation to a significant degree before it becomes a negative itself. Put forward by Michel Bréal under the name of contagion, this process is documented by Jack Hoesksema (2009) on the basis of items such as squat, jackshit and so on.
} 
Emphasis is a rather intuitive term. A definition cited by Schwenter (2006: 331) is that proposed by Israel (1998) of the emphatic unilaterally entailing the non-emphatic. $\mathrm{Ne}$ marcher pas would thus have entailed ne marcher, but not the other way around. What predictions this makes and how they are to be tested on literary texts of yore is uncertain: it is telling that such uncertainties carry to typological data, and that it cannot be established by van der Auwera's own admission whether many of the data he cites involve emphasis or not. A more testable perspective is proposed by Schwenter through the notion of activation. Schwenter (2005) observes that Brazilian Portuguese postverbal negation não occurs with preverbal não in a discourse-old proposition, which is accessible to both speaker and hearer, be it through previous explicit use of the sequence or through inference. Thus, in the following, the use of the postverbal negation with the verb vote alone corresponds to deny voting for a certain candidate, on the strenght of the previous mention of voting for that candidate:

A : $\quad$ O João votou no Lula?

'Did João vote for Lula?'

B1 : (Não.) Não votou não.

'(No.) He didn't vote (for him).' (p. 1445, example (17))

Contextual information is indexed because of the activated proposition that is required by the postverbal item. The preverbal negation in the answer to the same question does not

\footnotetext{
${ }^{9}$ The type of accessibility that concerns the proposition is quite different from the kind discussed in Giora (2007) that has to do with concepts under negative scope. The synergies between the two remain to be explored. Lahousse (in press) provides evidence that activation can concern phrases and not exclusively propositions.
} 
suppose an activated proposition and therefore does not index the information from the antecedent sentence; it thus simply denies voting at all:

B2 : (Não.) Ele não votou. ${ }^{10}$

'(No.) He didn't vote (for anyone).' (p. 1445, example (17))

The contrast indicates that an activated proposition is a necessary condition for the use of the postverbal negation in Brazilian Portuguese. The requirement is shown to characterise postverbal markers pas and mica in Catalan and Italian. An example of this is provided in the following, where it is not disagreement that allows B to use postverbal pas, as B concurs with A and is therefore unlikely to want to emphasise the negative, but the mere fact that the proposition was explicitly used and is therefore accessible to hearer and speaker alike:

A: La Maria ja no vindrà a aquestas hores.

the Maria already not will.come at these hours

'Maria won't be coming at this hour.'

B: Efectivament, la Maria no vindrà pas tan tard.

indeed the Maria not will.come NEG so late

'True, Maria won't come so late.' (Schwenter 2006: 334, example (4))

\footnotetext{
${ }^{10}$ One reviewer raises the question of the significance of the subject pronoun in (5) that is absent in the answer under (4). What comes to mind is that this absence might be related to anaphoric dependency, a speculation that seems supported by the data (Barbosa, Duarte and Kato 2005).
} 
As the emergence of postverbal markers is a central development of the negative cycle, it may be that it is promoted by activated contexts. That is the hypothesis formulated by Schwenter (2006) and taken up by Mosegaard Hansen and Visconti (2007). The latter seek to establish whether the emergence of a postverbal negative marker in early French and Italian is related to explicit activation. Such cases are attested:

$$
\begin{aligned}
& \text { "Se vous me voulés croire, ..." Il ne le vorent pas croire, ... } \\
& \text { (Joinville, P364-5) } \\
& \text { "If you'll believe me,..." They wouldn't believe him,... (Mosegaard Hansen }
\end{aligned}
$$
and Visconti 2007: 10, example (32))

but they are very much the minority case, and most instances involve implicit inferences brought about by lexical relations. The inference of ignorance deriving from not having been told something makes the second proposition in the following early French sequence accessible, which in turns allows the use of postverbal mie.

Ne l'oï dire, ne jo mie nel sai (Roland v. 1386) (Mosegaard Hansen and

Visconti: 22, example (101))

I haven't been told, I don't know it [at all]

The notion of activation could well constitute a better characterisation of the contexts promoting the emergence of postverbal items in the negative cycle, if only because it makes testable claims about the distribution of items. 
It is not only emerging items that are relevant to the Jespersen cycle, but also declining items. Such declines are illustrated by the preverbal item non in early French and by ne in the contemporary period. Could these declines be correlated to a pragmatic value such as activation? If this were the case, it would bring a reconsideration of the respective roles of pragmatic specialisation and frequency; frequency would not only reduce pragmatic contribution, it may also create it for increasingly lesser used items. It would also force a revision of the claim by Kiparsky and Condoravdi that pragmatic charge can only come from syntagmatic reinforcement, a claim which is already suspect given the fact that they themselves mention that "[y]es and no were originally reserved for emphatic assertion and denial, and supplanted their plain counterpart yea and nay in Middle English" (2006: 3).

Finally, the causal role attributed to frequency changes demands clarification. Increased frequency of usage is argued to turn a pragmatically charged negative into a standard one, and it may be that decreasing frequency turns a standard negator into a specialised one. Two important questions arise as to how both standard and marked negatives can be affected by frequency. First, as it is a gradual concept, if frequency affected the pragmatic import, this would mean that different degrees of emphasis or of activation should be observable; the difficulties in assessing emphasis alone make degrees of it impossible to diagnose; degrees of activation seem in the current state of knowledge to be an enigmatic concept. Secondly, why should frequency suddenly change for pragmatically specialised negators? Those particular values should constitute at any period a small proportion of all negative uses ${ }^{11}$, unless there are reasons to propose that speakers of a given

\footnotetext{
${ }^{11}$ There are no extended statistical data on this, partly because notions such as emphasis are difficult to apportion, partly because a representative sample of types of interactions is difficult to obtain. As an indication, Schwenter (2006: 338) cites Tottie (1991) who has found that $14.7 \%$ of all negative sentences in her British English corpus deny a prior affirmative.
} 
period become more emphatic as it were, reasons that we do not have ${ }^{12}$. It may however be that specific expressions become more frequent: of the 400 or so minimisers found in early French by Möhren (1980), only pas, point and mie become negatives ${ }^{13}$, with pas by far the most common form. Yet, even if pas were the only pragmatically marked form, would its frequency be enough to both diminish its specialised contribution and challenge ne alone as a standard negation? Surely, lack of special pragmatic role and the increased frequency for ne ... pas might well be a consequence rather than a cause of pas becoming the default negative. A rise in frequency cannot in and of itself bring about change of status. As the default negative should be the most frequent expression in the paradigm, accessions to default status should therefore explain rise in frequency. The default expression should provide a neutral pragmatic contribution, as "an obligatory element cannot be emphatic, for to emphasize everything is to emphasize nothing" (Kiparsky and Condoravdi 2006: 5). Obligatory must be taken to mean the default ${ }^{14}$ expression of sentence negation as opposed to marked items and structures $^{15}$.

\footnotetext{
${ }^{12}$ This would further go against the principle of uniformitarianism proposed by Elizabeth Traugott according to which communicative needs are stable across language varieties (see for instance Traugott 2003).

${ }^{13}$ These three markers are the only ones to appear in early legal texts, contrasting with the flurry of literary minimisers (Harald Völker, personal communication).

${ }^{14}$ The question arises of the diagnostic of the default expression of a category. By contrast to the distributional dependency of the marked, the default is the form which is not restricted in its distribution; neither morphosyntax, nor Semantics, nor Pragmatics, nor register is to stop the item being used as the spontaneous expression of the notion considered. It is to be found with the highest frequency, and as the first option with newly-coined items. Criteria of default status are thus productivity, frequency and context-independence. Productivity is discussed in interesting ways by the recent work of Bargdal (2009) and Elsig (2009).

${ }^{15}$ The notion of markedness used here in the sense of a specialised option such as emphasis or activation for the expression at a given time of a semantic category is not the markedness in the typological sense of a disfavoured form at any time across a semantic category by which negation is marked with respect to affirmation, passive with respect to active, plural with respect to singular etc. Insightful discussions of the latter are provided by Culicover and
} 
In other words, we propose that it is reanalysis as default negation that explains higher frequency, less restricted usage conditions and the absence of specialised pragmatic contribution, rather than the other way around. If this is correct, it means not only that the default structure is pragmatically neutral, but conversely that a specialised pragmatic import correlates to the marked expressions. Such a prediction would apply equally to emerging and declining expressions. The opposition between marked and default expressions would be central to the understanding of the Jespersen cycle and other grammatical changes.

The perspective outlined here not only has the advantage of doing away with degrees of discrete pragmatic categories supposed by a frequency-driven analysis, it also explains a puzzle relating to the competition of forms in language change. Change in grammar does not lead to an immediate change of available forms, which remain in competition. Thus, citing Parry (1997: 244), Floricic notes that "in certain dialects of Val Bormida, the three stages of the Jespersen cycle are synchronically attested, even if a priori the discontinuous negation represents the default case"16 (2005: 169; my translation, PL), as would be the case in Gascon (n. 14, p. 191); van der Auwera (2008) provides further examples of competition between markers and stages in the same language. This can be illustrated by the grammar of French negation and the three essential changes it has witnessed since the first records. The first is the disappearance of non as a preverbal negation where only ne remained. The second is the emergence of postverbal negatives. The last is the marginalisation of $n e^{17}$. At least three

Nowak (2002) and Haspelmath (2006). Both versions of markedness are used in the diachronic studies brought together by Andersen (2001).

16 "dans certains dialectes de la Val Bormida, les trois phases du cycle de Jespersen sont attestées synchroniquement, même si a priori la négation discontinue représente le schème non marqué"

${ }^{17}$ The decline of the averidical coordinating $n e$ replaced by $n i$ has been the subject of limited descriptive work (Badiou-Monferan 2005, Queffélec 1990) that has not led to explanatory consideration, probably because it contradicts the principle of the early expression of 
modes of negating the verb are thus available in Old French, non alone, ne alone ${ }^{18}$ and ne with a postverbal marker. Modern French retains ne alone, ne with a postverbal marker and the postverbal marker alone. Setting aside the preverbal use of non, this situation could lead to the belief that no change has taken place in the history of French negation. It remains the case ten centuries later that ne alone is still an option for the expression of negation (Larrivée 1995); it can yield focus, license NPIs and give way to double negation, as any negative item should (Larrivée 2004: chapter 1). This calls into question the various claims that pas in contemporary French is the only negation, which could just as well be expressed by ne. It is true that this option is specialised in its distribution, both in terms of formal written register and with respect to the averidical contexts in which it occurs (with modals and indefinites, in interrogative and conditional clauses). It has a lower frequency ${ }^{19}$ than the embracing negation that in the formal register constitutes the immediately available option in all contexts. The contemporary situation is in the end different from early French, the change being that French negation can be expressed not by one form surviving all others, not by the form being the only 'real' negation, but by that form becoming the default option while others are reanalysed as marked. This view is convergent with the discussion by Breitbarth and Haegeman of why marked preverbal negatives might be maintained:

negation (Larrivée 2004: chapter 2), and does not fit into any obvious cycle of evolution. How it relates to the frailty of the preverbal negative remains to be assessed.

${ }^{18}$ The extent of this competition is exemplified by the behaviour of ne alone in Old French. In the Anglo-Norman Correspondence Corpus, the first 100 occurrences yield, apart from 23 tokens of the homonymous coordinating conjonctions, 50 uses with some n-word (15 pas, 9 mie, 10 nul, 6 rien, 2 jamais rien, 1 mes, 1 unkes mais, 6 unkes), and 27 ne alone; of these, only 3 occur in otherwise veridical contexts, the rest being used with pouvoir (6), vouloir (3), savoir (1) and indefinite autre (2), and subordinated to a negative clause (1), a conditional si (7), a comparative (3), a correlative (1). Interestingly, these averidical contexts roughly correspond to those of modern French.

${ }^{19}$ Pouder (2008) indicates that $1.35 \%$ of sentence negatives are expressed by ne alone in a corpus of contemporary written academic texts. 
For a language to maintain such a preverbal marker for an extended period of time, this marker has to acquire further functional specialisation. (Breitbarth and Haegeman 2008: 4)

The proposal is that the changes in the grammar of negation equate to a change in the default marking of the category. The other means of expressing the category must then assume a specialised role. This division of labour between marked and default as a factor informing language change is what we assess for the three major changes identified in the history of French negation. We more specifically consider when the marked option can be said to be characterised by pragmatic activation, a plausible value for specialised expressions that can be readily tested. We hope to learn about the diagnostic of activation on novel data close to the vernacular, the contribution of pragmatics to grammatical paradigms and the central role of the opposition between marked and default expressions in language change. Section 3 looks at the disappearance of non in Old French, section 4 at the emergence of pas in Old French and section 5 at the disappearance of $n e$ in Contemporary French.

\section{Leaving stage I: Non in Early French}

The disappearance of preverbal $n o n^{20}$ from French negators seems never to have been taken very seriously. Few studies have dealt with it despite the fact that is it the only major

\footnotetext{
${ }^{20}$ As pointed out by one reviewer, this discussion does not include the case of nen, "an intermediate stage between non and $n e^{\prime \prime}$. I do not challenge that this should be considered in future work, and note that such work would need to resolve a number of difficulties. Nen presents considerable opportunity for homonymic clashes, as either a form of non, a version of néant or a contraction of ne plus partitive en (David Trotter, personal communication). The idea that nen is an intermediate stage needs careful assessment. Such an assessment will look
} 
innovation in the French grammatical paradigm of negation as opposed to its Romance counterparts. It furthermore contradicts the usual understanding of the Jespersen cycle, which is said to lie in the weakness of $n e$; it is the strong non that specialises and disappears first, with the last example attested in $1708^{21}$ (Reid 1939: 305, n. 1). The studies that consider the preverbal marker do so as a paradigmatic comparative to ne in the actual / virtual semantic system of Moignet (1965; see also Guiraud 1964, Martin 1972), and to nient by Taylor (1976). Only Reid (1939) ${ }^{22}$ offers a characterisation of the distribution of preverbal non modifying a finite $\operatorname{verb}^{23}$. In direct competition with $n e^{24}$, the use of preverbal non is characterised as "markedly affective" (p. 306). It is used for "denying the truth of a statement, but also making a negative reply to a question, and refusing to obey a command" (p. 306). It relates mainly to verbs avoir, être, to modals and to faire. The sequence is "always in some degree elliptical, the sentence being meaningless except with reference to what

at the chronology of forms and any differential function nen might have, as for instance the distributional difference found between English no, na and ne invalidates the view that they are mere variants (Okhado 2005). The functions of nen are the same as that of non according to Reid (1939: 313). Whatever the case may be, the issue of nen appears orthogonal to the discussion of the relationship between marked preverbal non and pragmatic activation.

${ }^{21}$ Interestingly, this is the period where coordinating particle ne disappears. Whether a connection is to be found remains to be determined.

${ }^{22}$ Thanks to Franck Floricic for bringing this paper to my attention.

${ }^{23}$ With occasional infinitives when they fulfill interactive functions such as prohibition in the following example cited by the Anglo-Norman dictionary:

Respundi la pulcele: 'Nu faire, bel frere, nu faire tel sotie' (Liv Reis 81)

"The maiden answered: 'Do not do, stepbrother, do not do such foolishness."'

This $n u$ may however result from the contraction of ne and le rather than be a version of non (David Trotter, personal communication).

${ }^{24}$ Which distinguishes this construction from others that have also disappeared, mainly the focusing si $X$ non (a.) and embedded uses in relatives (b.) (Buridant 2000: 702-5)

a. Mais n'ad talent li facet se bien nun (Roland, 3681; Reid 1939: 305)

"But he hasn't done his will if well not." i.e. 'He hasn't done it if he hasn't done it well', 'He has done it'

b. Je ne vous dois aconter qui le fist bien ne qui non (Merlin, 175, 63)

Je ne dois pas vous relater qui se comporta bien et qui se comporta mal (Buridant 2000: 703)

"I don't have to tell you who behaved well and who [did] not." 
precedes" (p. 306). It is accompanied by "formulas of asseveration such as certes, voir, par foi, par m'ame" (p. 306). These characteristics converge in the following illustration ${ }^{25}$ :

Juré l'avons et fiancié,

Cados, il fix mon oncle, et gié,

Que nos par force te prendrons

Et a mon oncle te rendrons,

Qui moult te het et mout t'a vil.

Por voi te di q'ensi ert il.

'For truth you-ACC say-PS-1PSG that so be-FUT-3PSG it'

- Non ert, se Dix me veit secorre.

'Not be-FUT-3PSG, if God me-DAT wishes help'

(Lancelot, Ille, 530-536; Denoyelle 2007)

"We have sworn and promised,

Cadox, my son's uncle, and I,

That by force we'll take you

And to my uncle give you back

Who very much hates you and holds you very much as vile

In truth I tell you that it will be so

- It will not be so, if God wishes to help me"

${ }^{25}$ Unless referenced, the glosses and translations are mine. 
The response where non modifies the verb be denies the antecedent assertion it will be so. It is elliptical, the manner complement is missing, and it refers specifically to the antecedent threat. The denial is reinforced by the expression if God wishes to help me.

Such reinforcements are not always present, and the verb involved varies.

Honte i avrai et reproche toz tans

'Shame I have-FUT-1PSG and reproaches all times'

- Non avrez, sire, dist Viviens li frans. (Aliscans, 204-5)

'Not have-FUT-2PP, Sir, said Viviens the noble-one'

J'aurais pour toujours honte et reproches.

- Non, seigneur, répond le noble Vivien. (Buridant 2000: 704)

"I will forever have shame and reproaches.

- Not so, Sir, answered the noble Vivien."

Dist Chantecler : Renart cousin,

Vos me volez traire a enging?

'You me-ACC want-PR-2PP draw at engine'

- Certes, ce dist Renart, non voil (RenartR, I, 4365-67)

'Certainly, this said Renart, not want-PR-1SG

Chantecler dit: Renart, mon cousin, vous voulez me berner.

- Assurément, dit Renart, ce n'est pas du tout mon intention. (Buridant 2000:

"Chantecler said: Renart, my cousin, you want to fool me?

- It is certainly not at all my intention, said Renart"

Nel ferez/ 
Par vos li mant qu'il nos soit secoranz

'By you him-DAT ask that he us-DAT be-SUBJ-3PSG rescuing

- Non feré, sire, dist Bertrand li vaillanz.

'Not do-FUT-1SG, Sir, said Bertrand the brave'

Vous lui demanderez de notre part de venir nous secourir.

- Non, seigneur, répliqua Bertrand le valeureux. (Buridant 2000: 704)

"You will ask him to come and rescue us

- I will not do so, Sir, replied Bertrand the brave."

Variation is found also in the speech acts accomplished: apart from the negation of an $\operatorname{assertion}^{26}(10)$, of a question (12), of a request (13), agreement with an antecedent negative assertion, and its extension to other arguments is also attested:

Je vous pri que ne me reffusez pas.

- Non feray-je, m'amie, par ma foy.

(Quinze Joye de mariage, v; Reid 1939: 309)

"I beg you that you do not refuse me.

- I will not, my dear, by my faith."

Le musnier fut content, et jamais plus n'en parla; non fist le seigneur que je sache (Cent Nouvelles Nouvelles, iii; Reid 1939: 308)

\footnotetext{
${ }^{26}$ This applies not only to root, but also to embedded clauses (see Chil Buriles disoit ke le terre ke Esclas tenoit devoit estre soi, et Esclas disoit ke non devoit "Chil Buriles was saying that Esclas' land should be his, and Esclas was saying that it shouldn't", Reid 1939: 307). Such cases are counterexamples to the claim by Godard and Marandin (2006) that only root clauses can host activated propositions.
} 
"The miller was satisfied, and never spoke anymore of it; the lord didn't either as far as I know"

What does not vary however is the dependence on an antecedent proposition that is overtly accessible. In other words, explicitly activated propositions license the use of preverbal non, that is not itself activated but used in a proposition that is ${ }^{27}$. The dependence on an antecedent proposition is shown by the information inherited from it by the elliptical sequence in which non is used ${ }^{28}$. That sequence can thus confirm the antecedent proposition, and not just contradict it: noted in the case of the Catalan example (5), this is observed in the two attestations (14) and (15) above, and casts further doubt that emphasis could be involved as emphatic negation seems to be associated with disagreement. Contextual dependency applies to the two illustrations set aside in the Anglo-Norman dictionary. The first is a straightforward denial of the explicitly activated proposition you know what he said:

$$
\begin{aligned}
& \text { Respondi Hieu: 'Bien le conoissiés et ce k'il a parlé savés'. Et il disent: 'Non } \\
& \text { savom' (Liv Reis 191; also Reid 1939: 307) } \\
& \text { "Hieu responded: 'You knew him well and you know what he said.' And they } \\
& \text { said: 'We do not." }
\end{aligned}
$$

\footnotetext{
${ }^{27}$ Preverbal non is thus different from the sentence-anaphoric use of non that still exists today; the latter clearly is context dependent given its anaphoric nature but does carry with it words used in the preceding context.

${ }^{28}$ That the construction is used with a limited set of verbs is true, but apart from the fact that there is a range of tense and person conjugations involved that should put in doubt any claim that an entirely set phrase is involved, it is tangential to the fact that the context is activated; a dependence on the antecedent context is found in the sequences where preverbal non is found whether they are a set phrase or not.
} 
The second does not seem to contain explicit activation, although the relationship between the evoked threat and the request for help qualifies as a case of inferred activation, as a help request can be expected in the context of danger:

sont en poynt d'estre anientisez si noun soit par le graciouse aide $[. .$.$] de$ vostre [...] seignurie (TextLett and Pet 75.46) 'are on point of be-INF annihilated if not be-SUBJ-3PSG by the gracious help of your Lordship'

"[They] are on the verge of being annihilated but for the gracious help of your Lordship"

It may be that this exemplifies a different structure such as the focusing one (mentioned in note 23), or possibly a case of implicit activation, the only one attested in the consulted resources.

The use of preverbal non thus relies on activated propositions, but not all activated propositions force the use of non, where ne can be used, especially from the 16th century (Reid 1939: 310-311):

Li lous crie: Tu me menaces!

'it-ACC him-DAT shout-PR-3PSG: You-NOM me-ACC threatens

- Ne fes, sire, salvez vos graces.

'Not do-PR-1SG, Sir, save-IMP-2PP your graces'

(Ysopet de Lyon, ed. Foerster, 84)

"He shouts to him: you're threatening me! 


$$
\text { - I do not, Sir, save your graces" }
$$

This illustrates the point by Breitbarth and Haegeman (2008) that special pragmatic contributions do not have to be signalled categorically. Optionality of pragmatic markers makes it possible for changes in default and marked status of existing expressions that are considerably simpler than wholesale semiological modifications. Several expressions can contrive to indicate a pragmatic value, and non can be accompanied by pas or nient as early as in the 12th century (Reid 1939: 309):

$$
\begin{aligned}
& \text { Ce sont bien les vostres, dit-il. } \\
& \text { 'It be-PR-3PP indeed the yours, say-PstHist-3SG-he } \\
& \text { - Les nostres! Non sont pas. (Des Perriers, Récréations, iii) } \\
& \text { 'The ours! Not be-PR-3PP not' } \\
& \text { "These are indeed yours, said he } \\
& \text { - Ours! Not so! }
\end{aligned}
$$

This of course supposes that pas would be marked for activation. Whether the markedness of emerging postverbal marker pas does indeed have a pragmatic import is considered in the next section.

\section{Entering stage II: pas in Old French}

A pragmatic contribution has been assumed to characterise the postverbal items pas, point and mie in the process of accessing default negative status. This assumption however has until recently rested on little empirical support. Such evidence is sought in the recent study 
of Mosegaard-Hansen and Visconti (2007), who evaluate the intervention of activation for the use of pas and mie in early French and of mica in early Italian. The French markers appear to have uneven relations with activation. Explicit activation does not define their distribution, as pas and mie are found in only five examples where they relate to an antecedent assertion:

"Biau Sire, fet Gauvains, donc me poez. vos bien dire, s'il vos plest, en quoi sui tiex come vos me metez sus." - "Je nel vos dirai mie, fet cie, mes vos troveroiz par tenz qui le vos dira.” (Graal, p. 52)

"Good Sir, says Gawain, then you can surely tell me, if you please, in what way I am that which you accuse me of." - "I'll not tell you, he says, but soon you'll find one who'll tell you.” (Mosegaard-Hansen and Visconti 2007: 15, example (66))

Distribution then has to involve inferred activation, a concept difficult to diagnose ${ }^{29}$ with certainty as it relies on implicit relations between notions. Let us consider this other example from the $13^{\text {th }}$ century Queste del Saint Graal:

$$
\begin{aligned}
& \text { Si fu cele nuit li rois molt a malese et molt pensiz por amor des preudomes de laienz qu'il } \\
& \text { avoit molt amez, qui l'endemain se devoient de lui partir et aler en tel leu ou il cuidoit bien } \\
& \text { qu'il demorassent longuement. Et por la demoree, se il la feissent, ne s'esmaiast il pas }
\end{aligned}
$$

\footnotetext{
${ }^{29}$ Criterial tests are proposed for contemporary languages in Larrivée (under evaluation) that involve putting the sequence under consideration in characterised textual environments, but these suppose acceptability judgements that can hardly be provided for states of languages where no native speakers are available.
} 
molt. Mes ce li met le grant duel ou cuer qu'il pense bien qu'il en morra grant partie en ceste Queste, [...]. (Graal, p. 21)

Thus, that night, the King was very troubled and much lost in thought out of love for his valiant men, whom he had loved very much, who were to leave him the next day to go to a place where he believed they would stay for a long time. And if they should stay absent long, he wasn't much troubled by it. But what greatly grieves his heart is that he thinks that many of them will die in this Quest, [...]. (Mosegaard-Hansen and Visconti 2007: 16-17, example (67))

Activation should be involved given the reinforced negation of esmaiat 'troubled'; while there is an evocation of the King being troubled in the sentence preceding and following the proposition under examination, they are realised by different lexical expressions ( $a$ malese, met grant due). Within the same sentence, it is not straightforward to infer a relation between other people being absent and someone being troubled. These uncertainties carry over to the use of the two other mie and the three pas with the same verb in the same text (from the concordances of the Base de français médieval). They do not associate with propositions that would be previously entertained in the preceding context any more perceptibly than in the seven cases where $n e$ is not reinforced. This is shown by the two following examples:

(22) a. Quant Perceval lor a devisee la maniere de la nef et des fuissiax, si dist Galaad : "Biax seignor, or nos covient aler quierre la damoisele qui ces renges changera et metra unes autres : car sanz ce ne doit nus ceste espee remuer de ceenz. "Et il dient qu'il ne savent ou il la truissent. "Et neporquant, font il, 
toutevoies irons nos volentiers en queste, puis que fere le covient. "Quant la damoisele qui suer Perceval estoit les oï si dementer, si lor dist : "Seignor, / ne vos esmaiez mie, car, se Dieu plest, ainz que nos departons i seront les renges mises, si beles et si riches come eles i covienent.

"When Perceval told them about the ways of the shuttles, Galaad said this: "Good Sir, it is now proper now that we fetch a lady who will change these sword-belts and put another : because without this none of us must take this sword from here." And they say that they don't know where he could find her. "And yet, they say, we will willingly go to find her, as it is proper to do so." When the lady who was Perceval's sister heard them lamenting in this way, she said to them: "Lord, do not trouble yourself, because, God willing, before we leave, the sword-belts will be put back, as beautiful and rich as they should be."

b. $\quad[\ldots]$ et lor demande dont il sont. Et il li dient. "Ha ! Seignor, por Dieu, fet ele, se vos poez si vos en retornez! Car, se Diex me consalt, vos estes venu a vostre mort ; et por ce vos loeroie je en droit conseil que vos retornez ançois que cil de ceienz vos sorpreignent dedenz les murs. "Et il dient qu'il ne retorneront mie. "Donc volez vos, fet ele, morir ?" -"Or ne vos esmaiez, font il. Car Cil en qui servise nos sommes entré nos conduira."

And she asks them where they are from. And they tells her. "Oh, Lord, by God, she says, if you can, you go back! Because, if God advises me well, you have come to your death; and because of this I would press you with the right advice to go back before those here find you within the walls" And they say that they will not go back. "Do you therefore want to die?" -"Now do 
not trouble yourself, they said. Because the one in the service of whom we have entered will lead us."

While (22b) contains a nice example of activated negation with mie in the negative answer to the invitation to go back, the negation of trouble does not appear any more or any less activated than in (22a).

Similar causes for concern are found by Lene Schøsler in the $13^{\text {th }}$ century chanson de gestes Le Charroi de Nimes. Some sequences have coordinated verbs one of which is negated with a reinforcement and the other not. The same sequence has simple negation in some of nine manuscripts examined, a reinforced one being found in others. [Similar objections are being documented on other texts by Richard Waltereit (Lene Schøsler, personal communication).] Some sequences in clear denial environments do not have a postverbal reinforcement in any of the manuscripts. This last difficulty is relativised by the fact that the clearly activated preverbal marker non is involved for verse 1087, and that a polarity expression por tot l'or desoz ciel 'for all the gold under the sky' establishes the strength of the denial in verse 1088. More generally, in line with the cited suggestion by Breitbarth and Haegeman, it may be that an activation value does not have to be marked, optionality accounting for the variability of marking across manuscripts and sequences. It may also be that sequences and verbs with postverbal markers do force accommodation of activated value, even when found in discourse-new contexts. These amount to the proposals that activated contexts need not be marked but that the sequences with the postverbal marker must be activated, which without some independent means of verification would lead to circularity. 
Such a context-driven property as explicit activation may be less likely to be found in literary sources. Such sources raise well-known issues for the representation of vernacular exchanges due to stylistic and register specificities of the literary. These difficulties are compounded by the fact that texts often exist in several transcribed manuscripts and are difficult to situate in terms of place and time of production, origins of author and nature of audience. Transcription errors, idiolectal, regional and social variation, genre conventions and stylistic effect can only be conjectured upon as the source of variation between manuscripts, texts and sequences. These reasons justify the use of complementary data. An examination was made of the Anglo-Norman Correspondence corpus. Put together by Richard Ingham, the corpus contains 50 Anglo-Norman letters written in the later $13^{\text {th }}$ and early $14^{\text {th }}$ centuries by ecclesiastical writers. Their author and recipient can be identified as can be the place and time of writing. As they represent non-literary exchanges aiming at the transmission of a message, these ordinary sources are likely to reflect a usage closer to everyday French. The actual pragmatic status of markers is thus more likely to be observed.

The search for ne yielded, after exclusion of coordination and contrastive constructions, 209 examples of the preverbal negative, of which 183 are free and 26 graphically agglutinated to the following verb or clitic. There were 29 cases of pas (one without ne), 46 of mie and mye (two without ne) and two point (one without ne). That makes for 213 negative sequences, of which point represents $0.9 \%$, pas $13.6 \%$ and mie $21.6 \%$.

The relatively small sample allows an examination of each example in its larger context with detailed attention to the pragmatic value of activation for the pas that is to 
emerge as the default marker. It is not primarily explicitly activated ${ }^{30}$. Activation of the verb ask in a subordinate may support that status for the main verb in the following:

Les poinz de qui il fet parole nus ne vous maundum pas, kar nuls ne les maunda a nus en especial.

"The points that he talked about we do not ask you, since none asked us specifically."

Doubts can be entertained that the use of believe in an antecedent sequence about an entirely different issue may make the subsequent use activated:

$$
\begin{aligned}
& \text { Sire, uncore vus pri jo ke vous eyez pite des freres, kar il ne furent unkes si } \\
& \text { maumenez en al Crestiente cum il sunt de suz vos meins, tut seit co cuntre } \\
& \text { vostre volente, si cum crey. Oveske co, sire, jo ne crey pas ke il eyent de ren } \\
& \text { fet cuntre la corone le rey. } \\
& \text { "Sir, I beg you again that you have mercy of the monks, because they were } \\
& \text { never so badly treated in Christianity as they are under your power, this }
\end{aligned}
$$

${ }^{30}$ One of the uses of point is with a verb that has been used in the immediately antecedent context:

a. $\quad$ et tout soit ensi qe les blees dedeins meisme le maner cressantz sont enmuriz, et mestier fuist qo ascun se entremeit de les faire entrer, par doute de perier, vous ne vous ent(re)medlez point, com faire duissez, a ceo qe nous est fait entendont,

"and it was such that the wheat inside growing in the same way were walled, and the service was that someone should have intervened to get it in, lest it withered, you didn't intervene, as you should have done, according to what we were told"

but this is not the case of the other:

b. Mes nous lui commaundames qil savisast soulement ovesque vous quoi seroit a faire de cel endroit. Parquoy nous nous agreoms point ceo que il ent ad fait.

"But we asked him whether to see with you what should be done in that place. Thus we do not agree with what he has done with it." 
against your will, as I believe. With this, Sir, I do not believe that they have done anything against the Crown."

A couple of other cases reasonably support the claim of inferable activation.

(25) a. Savoir vous fesoms qe nous avoms serche estreytement le dit composicion en presence de vostre tresorier, en la quele nest pas trove qe nous serrioms charge de tieu payement, solom les paroles contenues en la lettre le dit Ercevesqe, mais ceo qe duist estre paie en ceste partie, solom la forme de la dite composicion, deit estre paie en la tresorie le dit Ercevesqe a Caun-terbire, et nonpas pur vostre fee com la dite lettre Lercevesqe demaunde.

"We make it known to you that we have carefully looked at the agreement in presence of your treasurer, and in it it, it was not found that we would be charged of such payment, according to the words contained in the letter of the said Bishop, but what has to be paid in this part, according to the form of the agreement, must be paid to the treasury of the Bishop at Canterbury, and not to your fiefdom as the Bishop's letter requests."

b. Pour la queu chose esteyent recordez les articles de une parte de autre devaunt nus, e veymes ben e entendimes ke la descorde de vos bayliff e des nos surt de ceo, ke il ne entendent pas la composicioun en une manere kar ele est oscure en plusurs poynz.

"For that thing the articles were recorded before us from one party and from the other, and we could see and hear well that the disagreement between your 
baillifs and those deaf to him, that they do not understand the agreement in a way because it is obscure on several points"

The preceding act of looking and the contrast between parties' understanding make accessible the (not) finding and the (lack of) understanding ${ }^{31}$. Situation inference can be argued for uttering the message transmitted:

Sire, ne vous dioms pas cestes choses pur excusacioun, qar nous serroms prest, qant il plerra a Dieu, solomc nostre poair de faire vostre requeste.

"Sir, we do not say this as an excuse, because we will be ready, when it will please God, depending on our power to do what you ask."

Verbs of belief (27), knowledge (28) or desire (29) represent $27 \%$ of the uses of pas.

${ }^{31}$ The first example further contains a non-sentential contrastive construction nonpas, which constitutes accommodated activation. It recurs in two other occasions in the corpus:

a. Kar a la corone apartent nun pas soulement crueaute e reddur de justice, mes plus pite e misericorde.

"Because to the crown belongs not only cruelty and severity in justice, but even more pity and mercy."

b. Et auxi en voz dites lettres feut contenuz, qe, par procurement des uns de noz commoignes, ses enemys com est dit, par articles ne pas veritables et malement compassez, et collusions par eaux entremises, est atort grevez,

"And also in those letters of yours it was suggested that, by the persuasions of one of our monks, his ennemies as is said, by articles not truthful and badly constructed, and collusion between them, you unfairly wrong him"

Note that the non-verbal context does not forbid ne, which might be required to license pasand in other cases in the same corpus mie. One sentential contrastive case is attested.

c. $\quad$ pur co ke il nest pas en sa garde, einz e la nostre.

"For this he is not under his protection, but under ours."

The contrast can reasonably be argued to force accommodation of activation: the (c) example does imply that one could believe the person in question to be in the care of a third party. 
(27) a. E quei ke len die de ceste mesprisun, nus le poums pas bien creire, kar vous estiez si menable devaunt nus pur la honeur du Dieu e du roy, ke nus ne quidum pas ke vus en vousissez fere desray, nomeement cuntre la venue nostre seigneur le roy.

"And whatever people say of the misunderstanding, we cannot really believe it, because you were so agreable to us for the honor of God and the King, that we cannot believe that you wished to cause disorder, specifically against the visit of our Lord the King.

b. Sachez, sire, ke jo ai parle a ma dame la countasse solum la bulle quaunt a deus pointz ke ele contient. Le primer est ke li pape maunde ke jo me entremette de fere la peis entre vous e li. [...]. Sire, kaunt au primer, ele me respundi ke ele desirre la peis de vous et de li, plus ke nule chose qui seit en terre, e dit bien ke le ennui ke len li fet ele ne quide pas ke viegne de vostre quor.

"Be informed, Sir, that I have spoken to my lady the Countess following the bulle and the two points it contains. The first one is that the Pope request that I intervene to make peace between you and her. [...]. Sir, concerning the first one, she answered me that she wants peace between you and herself more than anything else that is on earth, and that despite the harm that is done to her, she does not believe that it comes from your heart.

(28) a. Sachez, sire, ke jo ai parle a ma dame la countasse solum la bulle quaunt a deus pointz ke ele contient. [...]. Le secund est, sire, sicome vous savez, ke jo la traie a ceo ke ele voile vouer chastete perpetuel, [...]. Al autre point, ele respundi ke ele neest pas avisee de vouer chastete, [...]. 
"Be informed, Sir, that I have spoken to my lady the Countess following the bulle and the two points it contains. The second one is, Sir, as you know, that I bring her to express the wish to chastity for evermore, [...]. To this other point, she answered that she is not determined to wish chastity."

b. Et pur ceo qe nous ne avoms pas connais-saunce de eaux, ne de lour poer ou nonpoer, fyablement nous les maundoms a vous, qe vous les apposez et, solom vostre discretion, taxez, et hastivement nous certifiez de la dite taxacion.

"And because we do not have any knowledge of them, of their power or lack thereof, we send them to you in trust, so that you question them and, to your discretion, tax them, and let us as soon as possible know of that taxation."

c. Sachez qe un Johan atte Welle et Richard le Hoppere nous unt quys et requys pur grace aver de meismes cele aide; et nous diens, qe vous lour demandetz dix marks, et qils vous tendent quarante soudz. Et pur ceo qe nous ne sumes pas uncore avyse quey nous dyoms faire endroit de cele grace, nous vouloms, si vous veiez qe fest afaire, qe vous recevez les xl. soudz qils tendent, [...].

"Be informed that a certain Johan atte Welle and Richard le Hoppere asked us and asked again to have the favourable treatment of such a help; we said that you are asking them ten marks, and that they offer fourty penny. And because of that we have not decided what we should do with respect to that favourable treatment, we would like, if you think this would do, that you accept the fourty penny they offer."

d. Et par ceo qe nous ne sumes pas certifiez si execution de toutes les choses avant dites soit fait ou ne mye; nous voloms qe, quant a taillage de noz 
vilains, si ils ne soient mye taillez qils soient taillez solom la forme avantdite, et qe execucion soit fait de cele taillage ore a la feste de Seint Michel proschein avenir;

"And because we have not been guaranteed that the execution of all the things mentioned before have been done or not; we want that the taxation of our villein, if they have not been taxed that they be in the way mentioned before, and that the taxation be executed before the soon approaching SaintMichel celebration."

(29) a. Pur la queu chose nus vus maundums, ke pus ke li roys, par ke vous gardez le chastel, ne ly vout pas ottrier la parole auvant ditte, [...].

"Because of this, we ask you, that since the King, from whom you hold the castle, does not want to grant the word mentioned before."

b. Sire, jo rescu vostre lettre le jur Madame Seinte Cecile, e entendi ben pa vos lettres, ke vus ne avez pas volente de grever les Freres, "Sir, I received your letter on the day of Our Lady Sainte-Cecile, and understood well through you letter that you do not have any intention to burden the Monks."

To the category of desire could be related the negation of having a reason to act, as the lack of trust could be to belief, as all evoke conditions that precede the actualisation of an event.

(30) a. Mais qant a Robert de Derteford; ne vous desplese, kar nous ne avoms pas cause verroye daustier celuy qi est ore en le office ou le dit Robert feust, 
"But concerning Robert de Derteford; may this not displease you, because we do no have any real reason to remove the man who is still holding the job where this Robert was."

b. Dautrepart vous savez bien coment vous avyez les overaignes de noz bestes entour la gaignerie des ditz bletz; de quoy vous ne avez rien parle a nous, ne a noul des noz pur nostre assez faire en noule manere, come vous seriez bien tenuz solom ley et resoun. E nepurquant nous nous ne asseuroms pas en vostre conscience, qar nous ne avom trove unquore fesqe parole et rien de fait.

"On the other hand you well know how you had the responsibility of our animals around the said fields of wheat; of those you didn't tell us anything, as you had to by law and reason. And thus, we do not trust in you, because we have found only words and nothing done."

The cases from (27) to (30) present a paradox. The subordinate often closely corresponds to an antecedent proposition, that could motivate activation and reinforced negation, as in (28a); yet, the reinforcement appears on the main verb. Reinforcement could be explained by the presumption that the information discussed is available to writer and correspondent, but that cannot be established with certainty. The degree to which shared information can be ascertained is therefore problematic.

Similar problems arise in denial of the appropriateness of a situation:

(31) a. Pur quei, se ceo est veirs, jeo vus maund cumme a amy, ke vus facet ces choses amender, issi ke il ne coveyngne pas ke jeo y mette la meyn 
"Because of this, if it is true, I ask you as to a friend, that you have these things modified, as it is not appropriate for me to do so."

b. Qar si hom les eust greve a tort, il deveroient plus tost avoir monstre la chose a nous qe a vons, qe verroiement, Sire, ceo nest pas mout covenable chose ne honeste de vous meller entre nous et noz vileyns, nient plus qe nous fesoms de voz vileyns de Tuvertone on aillours.

"Because if a man had wronged them, they should have shown this to me rather than you, that really, Sir, it is not a very appropriate or honest thing that you stand between us and our villeins, no more that if we would do with your villeins in Turvertone or elsewhere."

c. kar jo bei abatre ceste eslaundre si Dieus men doint le poer, ne jo ne le puis pas lesser saunz graunt pecche.

"because I will put an end to this slander if God gives me the strenght, and I cannot leave it at that without great sins."

and in the imputation of inappropriate behaviour in others:

(32) a. Sire, nus avuns entendu [...] ke lendemayn de la Penthecuste [...], vint a Abyndon' le counte de Herefored devaunt nos treschers seignieurs e amis le eveske de Duraume e le counte de Cornwaillie, proposaunt a affermaunt ke vous ne avez pas tenu les covenaunces euues nad geres entre vous e li.

"Sir, we have heard that the day after the Pentecost, there came to Abyndon the Count of Hereford before our very dear Lords and friends the Bishop of 
Durham and the Count of Cornwall, suggesting and asserting that you had not held the agreement made not long ago between you and him."

b. Nous avoms entendu bien vostre Letre et vostre propre volunte, dount nous avoms grant doel et tristour de cuer, de ceo qe nous veoms bien qe vous nestes pas si religiouses come apartendreit.

"We have understood well your letter and your will, of which we have great pain and sadness, from what we see that you are not as religious as would be proper."

c. Et, Sire, sil voille dire la verite, come il nest pas acustume, il mesmes vous grantera bien qil ad este sovent excumenge de nous et noz Officiaux, et apres venu et este assoutz.

"And, Sir, if he will say the truth, as he is not used to, he himself will well agree that he has often been excommunicated by us and our Officers, after which he came and was absolved."

The imputation of economy with the truth to a third party is insistently repeated in the letter at the end of which (c) figures, (b) opens the letter by regretting that the nuns are breaking their obedience vows by their request to change confessors, (a) reports of breech of agreement on the part of the addressee. It may well be that the information is likewise accessible to both writer and reader before the letter, which would be the only way to claim activation for what appears to be out of the blue denial that cannot otherwise be conceived of as discourse-old. Appealing to common-ground in the widest sense of the expression would similarly be necessary in the following: 
(33) a. Et voillez savoir, qe le poy de meryn qest demorez en noz boys de Longebeche et de Reggesterne ne suffit pas a la sustenaunce de noz mesons et de noz moleyns qe nous avoms en cel pays.

"And do know that the weight of the big trees left in our woods of Longebeche and of Reggesterne is not enough to the maintenance of our houses and our mills that we have in that county.

b. [...] kar sachez ke celuy Thomas cum jo ay entendu, puis ke jo vus escris autrefez, $[\ldots]$ nest pas bigames, [...].

"And be informed that this Thomas, as I have heard and then wrote to you in the past, [...] he is not bigamous."

c. [...] jo li conseilai e defendi ke ele sei ne parte pas de cest pais deskes ataunt ke jo aie parle a vous a leisir, e sasche plus pleinement vostre volente, e deske la chose se aprochast a aucune bone fin.

"I advised and forbade her that she herself not leave from this county until I speak to you and know your will better, and until the affair gets near a positive result."

d. [...] et Pierres Galeys nest pas profitable pur nous.

"And Pierre Galeys is not useful to us."

Shared information is credible for (b) as the denial of the accusation of bigamy is said to have been made in a prior letter; previous mention of the fellow named in (d) is plausible although not found in the letter itself; quantities of wood have been discussed in the letter where (a) appears but not their sufficiency, which might have been in prior correspondence; 
the intimation that the third party stays put is however not likely to have been previously evoked and could constitute new information.

There are three final attestations of pas occurring in general statements not previously used in the letter.

(34) a. [...] serroms prest de assentir [...] issint la Commissioun soit fete a nous du Prelat lautre; qar il ne apent mye de faire Commissioun a nul qe nest pas Prelat du poair de Prelat, [...].

"We will be ready to agree as long as the Commission is made to us by another prelate; because it is not fitting for someone to make a Commission who is not prelate of prelate power."

b. $\quad[\ldots]$ qele chose nest pas signe saver; qar len dyt en Fraunce qe nul nest fol qe ne quide estre sage.

"These things are not a sign of knowledge; because it is said in France that noone is a fool who does not believe to be wise."

c. $\quad[\ldots]$; qar Dieu nest pas acceptour de persone.

"Because God does not wrongly scrutinise people."

Where the first example may be activated as it provides a possibly well-known explanation as to why a request must be made by another religious figure, activation seems absent with the two other out of the blue negated statements.

The status of emerging postverbal pas raises considerable uncertainties. On a strict interpretation, 5 out of 29 attestations in the letter corpus examined might be considered as activated, which could be attributed to all but the last two on a generous account. It may be 
that the data available to us and to Mosegaard Hansen and Visconti are simply too late: after

all, postverbal reinforcement is already attested in Late Latin (Orlandini 2001: 70-71). It may be that we need better data: although better reflecting ordinary usage, letters do not provide for the sort of direct dialogal disagreements that is a favourite context of explicit activation. In the absence of the missive to which a letter is responding, we can only assume with various levels of certainty that an issue was part of the preoccupations of the correspondents. More certainty might be afforded by direct exchanges between two parties. Such exchanges may be found in reports of contradictory legal proceedings such as found in the Anglo-Norman Year Books. An investigation of such sources should be pursued in view of the fact that a significant portion of the uses of postverbal items in the limited corpus consulted here involves some reasonable evidence of activation. Whether such evidence can be found for $n e$ in the contemporary period is considered in the next section.

\section{Leaving stage II: $\mathrm{Ne}$ in Contemporary French}

Despite the uncertainties as to the contribution of emerging sentence negation ne ... pas, the case of preverbal non shows that obsolescence of a form may be related to functional specialisation of a pragmatic nature. This raises the question as to whether such a specialisation is associated with declining ne in contemporary French.

Preverbal ne is indeed declining in French, and has been for a long time. Early texts from Anglo-Norman, Flanders and Luxembourg areas evidence ne drop (Gregory 1997, Ingham in press, Völker 2007). Examples from France are found at least from the $17^{\text {th }}$ century (Blanche-Benveniste and Jeanjean 1986), and become increasingly frequent in the $19^{\text {th }}$ century in informal communication (Ayres-Bennett 1994, Ashby 1981, Martineau and Mougeon 2003, Martineau 2008a). Formality is signalled by the use of ne, which remains 
available to speakers when they need to resort to it. This is demonstrated by the Posh Ladies experiment conducted by Claire Blanche-Benveniste's team: children invited to pretend to be posh ladies in a chic restaurant start producing different markers of formality including ne (Blanche-Benveniste et al. 1990: 257) ${ }^{32}$. Other studies claim that the decline of $n e$ is a change in progress. Amongst a great many, the most striking work is that conducted by Ashby (further references to comparable work and a general discussion is provided by FonsecaGreber 2007: 250-253). From sociolinguistic interviews of a representative sample of the population of Tours conducted in 1976 and again in 1995, he establishes that ne is less frequent by nearly $20 \%$ across all segments of the population. That a change is in progress for an item is not incompatible with its availability; on the contrary, the availability of an item is obviously a precondition for it to undergo change.

Declining ne could be associated with a pragmatic contribution over and above its stylistic variable status. The idea is first pursued by Mary-Annick Morel (1994). She claims that $n e$ is maintained in contexts of dialogic involvement. The notion has a vagueness that makes its evaluation difficult in the provided corpus of conversations. A corpus of informal exchanges between friends recorded at home is analysed by Fonseca-Greber (2007). She shows that the middle-class speakers of Swiss French concerned retain the preverbal negative in less than $2.5 \%$ of cases $^{33}$. The rarity of the marker therefore raises the questions of the reasons for its insertion rather than for its drop. Ne insertion is proposed to have two functionalities. One is register, and micro-shifts in register motivate the occurrence of the preverbal marker in the following:

\footnotetext{
${ }^{32}$ One reviewer raises the possibility that children's perception of formality markers might differ from that of the adult community. Study of the adult's production and perception would be useful in apportioning this.

${ }^{33}$ Even lower frequency is found in the socially representative corpus of Quebec French by Sankoff and Vincent (1977).
} 
le système judiciaire américain permet cela... tandis que chez nous il ne le permet pas (Fonsecas-Greber 2007: 258, example (3))

"The American justice system allows this... whereas here, it does not"

A second, emerging function is the pragmatic value of emphasis signalling speaker evaluation or involvement. It appears mainly in foregrounded clauses with other emphatic markers such as pitch prominence, slower speech, lexical emphasis, contrast and repetition. The lexical intensifier strictement, the use of negative aucune where a more neutral option such as pas would be possible, and the use of ne would connive to communicate emphasis in the following:

j'ai entendu des patrons qui mettaient une plaque au four... qui r'venaient... elle etait brûlée... pis qui engueulaient un apprenti... l'apprenti n'avait

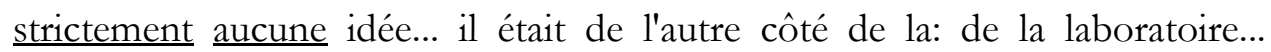
(Fonsecas-Greber 2007: 261, example (12))

"I've heard bosses who put a plaque in the oven... they came back... it was burnt... and they told off the apprentice... the apprentice had strictly no idea... the were on the other side of the lab..."

which voices the outrage of the speaker at the treatment of the assistant in question.

While the two functions of emphasis and register are kept well separated by the author, the relation between them seems fairly transparent. It would seem that the emphasis communicated by the preverbal negative derives from its register status; the formality of ne 
would in informal conversation emphasise the speaker's message. That pragmatic contribution should be observable in other similar oral exchanges. A comparable series of exchanges $^{34}$ is accessible at the online Lancom corpus providing transcriptions of videotaped role-plays between French students. While the interactions are at least in their initial terms directed and take place in a School setting, they offer informal verbal exchanges that are freely accessible and searchable. An examination of the forty-four attested ne does yield one unambiguous case of pragmatic emphasis. The following extract:

qu'est-ce que t'en penses de ce film?

-ben moi dans l'ensemble j'ai bien aimé ça retrace bien l'histoire des mineurs

-ah bon ben justement moi je trouvais que c'était un film euh un peu moyen

je ne l' ai pas trop aimé moi je trouvais qu'il ne retraçait pas tellement ce qui se passait avant

"What do you think of that film?

- On the whole, I liked it, it tells the story of the minors well

- Well, I thought that it was a film... a little average... I did not like it much... I thought it did not really show what was going on then

offers a disagreement between two speakers about their appreciation of a film, and although this is signalled twice by $n e$, it could hardly relate to emphasis. Its definition as entailing the simple negation is contradicted by the intervention of mitigation through negation of much

\footnotetext{
${ }^{34}$ The new online corpora of spontaneous speech Discours sur la ville - Corpus de Français Parlé Parisien des années 2000 (CFPP2000) reveals a similar situation to that in Lancom.
} 
and really: for one not to like something much does not suppose that one dislikes it. The other uses of the verb like do not further the case. The example below provides a mitigated and unmitigated disagreement that contains no ne despite the strength of the initial reaction:

- bon et bien si on allait manger au Mac Do?

-ah non j'aime pas trop le Mac Do c'est pas bien le Mac Do non j'aime pas

$[\ldots]$

-bon allez c'est bien le Mac Do c'est super on s'y amuse bien c'est pas cher

"So, what about going to eat at McDonald's?

- No way I don't like McDonald's It's no good MacDonald's no I don't like it

- Come on McDonald's is nice, it's great, we have fun there and it's not expensive

A $n e$ is provided in the following despite the fact that there is no signaled emphasis, no disagreement about backgrounded information:

- le weekend qu'est-ce que vous aimez faire le weekend?

- ben ce que j'aimerais faire [...] c' est faire ce que j'aime bien [...] donc c'est ça que $j^{\prime}$ aimerais faire par contre je fais des tas de choses que que je n'aime pas faire et que je suis obligé de faire mes semaines débordant sur le weekend "What do you like to do at weekends? 
- Well what I'd like to do is to do what I like. That's what I'd like to do. On the other hand I do lots of things that I don't like to do and that I have to because the week is spilling over in to the weekends.

Data are therefore far from unambiguous in their indication of the potential role of emphasis for the occurrence of declining ne in informal exchanges (a confirmation of this ambiguity is provided by van Compernolle 2009). The idea that the preverbal negative may be associated with different pragmatic contributions because of its formality status deserves more consideration and may lead to a criterial test being developed for the proposed values. Such tests may well be useful for formality, which remains the specialised contribution of ne. This specialisation alone supports the view of a paradigmatic opposition between marked and default for grammatical change.

\section{Conclusions}

This paper considers the question of why new ways of expressiong negation should arise in French to form new stages that constitute a cycle. New concepts are used to frame the answer in terms of the opposition between marked and default expressions and the specialised contribution of marked expressions. The opposition between the marked and the default structure grammatical paradigms, and changes in them correspond to default status being conferred on a different expression. The default expression of sentence negation in French goes from ne alone to ne ... pas to pas, forming a cycle of stages from the preverbal to the postverbal ${ }^{35}$. At each stage, the emerging and declining marked expressions take on a

${ }^{35}$ As pointed out by a reviewer, this looks more like a linear process than a cycle. For a full assessment of the notion of cycle for French negation, see Larrivée (2009). 
specialised role. Such specialisation may correspond to pragmatic values. The pragmatic value of emphasis has been found an ill-defined concept that is difficult to diagnose. This contrasts with activation that on the basis of its definition as information accessible to the hearer, can be readily tested. Explicit activation characterises the contexts in which marked preverbal non is distributed in Old French. The presumption that emerging pas might rely on activation (Schwenter 2006, Mosegaard Hansen and Visconti 2007) is demonstrated to be unsupported. The point that pragmatic hypotheses about grammar change must be tested is pressed again in relation to impressionistic suggestions about the contemporary pragmatic status of declining ne, which retain a register specialisation.

Paradigms thus change (and presumably vary across social and geographical dialects $^{36}$ ) because marked expressions exist that can replace the default option. One of the reasons why marked expressions exist is to express pragmatic values ${ }^{37}$. As every language must have a default expression of negation, the need for change arises when the existing default fails to sustain its status as the more productive, more frequent and more contextindependent expression. The evolution in the status of ne has an impact on the emergence of pas and on its own decline, and can be speculated to relate to its syntactic specialisation. As a

\footnotetext{
${ }^{36}$ An illustration of this mechanism relating to variation is documented by Hack (2009), who shows that in the Dolomitic Ladin dialects where particle $p a$ becomes a compulsory total question marker, it has lost all the 'emphatic' values it has in the varieties where it is not required.

37 Among these pragmatic values is the denial of a previous assertion represented by activation. Denial of a previous assertion is often identified as the basic function of all negatives in the research tradition, according to one reviewer who points to Givón, Horn and Miestamo. It is true that Givón and Horn discuss the informative asymmetry of negation, but they do not to my knowledge assert that all negatives represent denial. If denial were the function of all negatives, then clearly that would make the notion of activated negation redundant. The way in which this notion is distinctive is that it supposes material accessible to the hearer rather than just to the speaker, and that in this sense, sequences like She wasn't moving, she wasn't breathing, we couldn't do anything are in most cases not normally activated while being certainly negative.
} 
preverbal clitic, it has no prosodic autonomy, which threatens the perception of the polarity of the sentence that postverbal pas clarifies. It also lacks syntactic autonomy and cannot be used in a series of contexts such as the second member of coordinated group and fragment answers where pas can be found. This might have led pas to be interpreted as the unmarked expression of negation, pushing ne to a stylistic value especially found in the written medium where it is most easily recognised, a value that explains its existence to this day. This means that the parts of discontinuous markers may come to be treated independently, as discontinuous markers may come to be understood as one option. Marked options are maintained, or disappear altogether if they lose their special contribution or fail to become default markers. The well-established ne ... pas does not allow marked non to gain default status, leading to its obsolescence after a longish period of competition.

This work is conclusive in a number of important ways. It substantiates the view that grammatical paradigms are shaped by the relation between marked and default expressions. It thus allows sense to be made of change (and variation) in paradigms and of long-standing form competition. It furthers the idea that marked expressions may be associated with pragmatic values. It adjudicates the debate as to whether the best pragmatic characterisation for marked competing forms in the history of French negation should be emphasis or activation. That explicit activation is the pragmatic value of contexts with marked preverbal non in Old French is demonstrated on the basis of hard evidence. Novel data close to the vernacular invalidate the hypotheses about the activated value of $p a s$ and $n e$. The examination of these provide criterial observations to identify the intervention of emphasis (its affinity with denial, the presumed incompatibility with hedges) and activation for emerging and declining expressions. The theoretical role of pragmatics for decline, emergence and competition of items is identified as supporting the specialised contribution of marked 
expressions. A notional framework is thus provided for language change in grammatical paradigms, which corresponds to a marked option becoming the default expression.

The results from this work points to a series of new research directions. It would be useful to confirm the activated status of non and the conditions of its decline in a larger set of sources, and to consider whether a similar scenario applies to other markers such as nen or néant. Whether the emerging postverbal reinforcement signals activated propositions is still very much uncertain, and more work using dialogal sources such as the Anglo-Norman Year Books may show that something like emphasis rather than activation is involved, for instance. What pragmatic effects the register status of ne may have remains a new area of investigation. How items can sometimes be analysed as parts of a syntagmatic marker, and how the parts can be reanalysed as different expressions is something that requires elucidation: one thing that troubles me is not so much that ne goes its own way as it were, but that pas and point are in competition while at the same time being two instantiations of default embracing negation. It may be that the default is the embracing negative irrespective of the postverbal element that instantiates it, which would tally with the normative uncertainties in the $17^{\text {th }}$ century about which item to use (Martineau 2008a), and that the default status acquired later by pas effectively pushes point into a marked, regional, archaic and sometimes 'stronger' negative.

What this work has not done is provide an analysis of critical moments of change from one default expression to the next, from default to marked, or from marked to default or obsolescent. How this occurs can however be speculated upon with some level of conceptual confidence. Grammatical paradigms change because an existing marked option is reanalysed as the default expression. This reanalysis occurs in bridging contexts that present ambivalence as to whether the specialised contribution that characterises the marked option 
can be understood as absent. Indeed, if being a marked option means for a marker to have a specialised contribution, and if the properties of that contribution can be interpreted as absent in a context, then the marker has the potential to be understood as a default candidate. The reanalysis of a marker as default will lead other expressions to become marked. These become associated with specialised properties through use in a context that is convergent with such a reanalysis. This means that it is reanalysis that is the cause of massive frequency changes, and not the other way around. Of course, minor frequency changes may be one of the factors by which a marker is to be reanalysed, but it should be the reanalysis itself that explains the bulk of frequency changes, as there are no data showing a spectacular increase of a marked option or a spectacular decrease in a default marker without there having been a reanalysis of their status. Frequency is a consequence, not a cause of change ${ }^{38}$. Identifying reanalysis as the cause of change allows external linguistic factors to be taken into account. For French, the choice of ne ... pas over ne and over point and mie would be explained by the sociological fact of its adoption by the French chancery (Völker 2007). The preverbal marker ne that signals formal registers would have withered had it not been for mass education $^{39}$ in the $20^{\text {th }}$ century (see data from Martineau 2008a). Social ratification of markers supports their analysis as default or marked, and contributes to their subsistence or obsolescence.

\footnotetext{
${ }^{38}$ On reviewer notes that "presumably there are some cases (e.g. morphological regularisation) where (in)frequency drives (rather than follows) change." This conclusion could only be supported by extensive quantitative data for which the possibility of any status change would be excluded, certainly a desirable endeavour for future research.

39 One reviewer notes that the "explanation by prescriptive teaching is not sufficient: expletive negatives were in any time criticized by normative grammarians, and nevertheless are always in use, sometimes against normative grammar." Indeed, it is not teaching itself, but rather the specialised contribution of the item reinforced by teaching that ensures its longevity.
} 
The succession of default negative markers does form a morphosyntactic cycle from the preverbal to the postverbal. Why that is can be explained by the way in which new negatives are often formed. New negative expressions in many languages start life as polarity items. Negative Polarity Items will either follow the negative immediately (as with Latin non from ne + oenum 'not + a thing'), in which case there is a change of particles, but not of stages; or mediately (as with ne $V$ pas), which represent the second stage of the cycle; crucially, things can only move forward, as any polarised reinforcement can hardly precede the negative. It must be noted of course that such a cycle is not mandatory; it is made possible by the decline of the preverbal default option and the reanalysis of a marked expression that is found postverbally.

The relation between marked and default, the reanalysis of a marked expression as default, the specialised contribution of the other expressions that explain their subsistence, their possible but by no means necessary obsolescence provide a good narrative for cycles of grammatical change. It accounts for the diversity of markers and the extended period of their competition. It tells us what is characteristic of a language at a given stage, to what extent its varieties are structurally similar, how it is different from other languages in the same group and from itself in other periods. Whether that narrative tells the whole story can only be determined by more work on data representative of past vernacular usage, which I hope to pursue in future research.

\section{Acknowledgements}

This work finds its impetus in discussions with participants of the Leverhulme Research Network Cycles of Grammaticalization (http://www1.aston.ac.uk/lss/research/researchprojects/cycles-of-grammaticalization/), and earlier versions benefited from the detailed 
observations of Claire Blanche-Benveniste, Richard Ingham, France Martineau and Johan van der Auwera, as well as from the challenging questions from the three reviewers and the editor of this journal. They helped me focus the proposals in a number of ways, and any residual vagueness must remain my own responsibility.

\section{References}

\section{Resources}

Anglo-Norman Correspondance Corpus. http://www.lhds.bcu.ac.uk/english/anglonorman-corpus

Elicop. http://bach.arts.kuleuven.be/pmertens/corpus/

The Anglo-Norman Hub. http://www.anglo-norman.net/

\section{Studies}

Andersen, Henning, 2001. Actualization. Linguistic Change in Progress. Amsterdam and Philadelphia: Benjamins.

Ashby, William J., 2001. Un nouveau regard sur la chute du ne en français parlé tourangeau : s'agit-il d'un changement en cours ? Journal of French Language Studies 11,1, 1-22.

Ashby, William J., 1981. The loss of the negative particle ne in French: A syntactic change in progress. Language 57,3, 674-687.

Ayres-Bennett, Wendy, 1994. Negative evidence: Or another look at the non-use of negative ne in seventeenth-century French. French Studies XLVIII,1, 63-85.

Badio-Monferran, Claire, 2005. Psychomécanique et évolution de signifiant: le cas du coordonnant négatif à l'aube du français moderne. Langue française 147, 84-97. 
Barbosa, Pilar, Maria Eugenia L. Duarte and Mary A. Kato. 2005. Null Subjects in European and Brazilian Portuguese. Journal of Portuguese Linguistics 4,2, 11-52.

Bargdal, Jóhanna. 2008. Productivity. Evidence from Case and Argument Structure in Icelandic. Amsterdam and Philadelphia: Benjamins.

Blanche-Benveniste, Claire, Mireille Bilger, Christine Rouget, Karel van den Eynde and Piet Mertens, 1990. Le français parlé. Etudes grammaticales. Paris: CNRS.

Blanche-Benveniste, Claire and Colette Jeanjean, 1986. Le français parlé. Transcription et édition. Paris: Didier Erudition.

Bréal, Michel. 1897. Essai de sémantique, science des significations. Paris : Hachette.

Breitbarth, Anne and Liliane Haegeman, 2008. Not continuity but change: stable stage II in Jespersen's cycle. MS, University of Cambridge and CNRS. 22 pages. Available at http://www.hf.uio.no/tekstlab/negasjon07/abstracts.html

Buridant, Claude, 2000. Grammaire nouvelle de l'ancien français. Paris: Sedes.

Culicover Peter W., and Andrzej Nowak. 2002. Learnability, markedness, and the complexity of constructions. Pierre Pica and Johan Rooryk (Eds). Language Variation Yearbook 2. Amsterdam: Benjamins. 5-30.

Dahl, Östen, 1979. Typology of sentence negation. Linguistics 17, 79-106.

Denoyelle, Corinne, 2007. L'emploi des particules adverbiales oui et non dans quelques textes littéraires médiévaux. L'Information grammaticale 112, 3-8.

Detges, Ulrich, and Richard Waltereit, 2002. Grammaticalization vs. reanalysis: a semanticpragmatic account of functional change in grammar. Zeitschrift für Sprachwissenschaft 21, 151-95.

Dryer, Matthew S. 1996. Focus, Pragmatic Presupposition, and Activated Propositions. Journal of Pragmatics 26, 475-523. 
Eckardt, Regine, 2006. From Step to Negation: The development of French complex negation. Meaning Change in Grammaticalization: An Enquiry Into Semantic Reanalysis. Chapter 5. Oxford: Oxford University Press.

Elsig, Martin. 2009. Grammatical variation across time and space. The French interrogative system. Amsterdam and Philadelphia: Benjamins.

Englebert, Annick, 1985. L'opposition ne / ne ... pas en ancien français. Revue de Linguistique Romane 196, 365-78.

Englebert, Annick, 1984. Esquisse d'une histoire de la négation en français. Travaux de Linguistique 11, 7-25.

Floricic, Franck, 2005. Aspects de la négation dans les langues romanes. Lalies, 25, 163 - 194.

Fonseca-Greber, Bonnibeth Beale, 2007. The Emergence of Emphatic 'ne' in Conversational Swiss French. Journal of French Language Studies, 17,3, 249-276.

Gardiner, A. H., 1905. The word. Zeitschrift für Ägyptische Sprache und Altertumskunde $41,130-135$.

Giora, Rachel, 2007. A good Arab is not a dead Arab - a racist incitement: On the accessibility of negated concepts. I. Kecskes and L. R. Horn (Eds). Explorations in Pragmatics: Linguistic, Conitive and Intercultural Aspects. Berlin: Mouton de Gruyter. 129-162.

Godard, Danielle and Jean-Marie Marandin, 2006. Reinforced negation: The Case of Italian. Stefan Müller (Ed.). Proceedings of the HPSG06 conference. Stanford: CSLI.

Gondret, Pierre, 1981. Les pronoms et déterminatifs indéfinis dans les phrases négatives en français du douzième au seizième siècle. Thèse de doctorat d'Etat, Université de Paris IV. 
Gregory, Stewart, 1997. Negative particles in French prose of the twelfth century. Stewart Gregory et David A. Trotter (Eds). De mot en mot: Aspects of medieval linguistics. Essays in honor of William Rothwell. Cardiff: University of Wales Press. 37-51.

Guiraud, Pierre, 1964. L'opposition virtuel / actuel : remarques sur l'adverbe de négation dans Aucassin et Nicolette. Mélanges offerts à M. Delbouille. Tome 1. Paris et Gembloux: Duculot. 295-306.

Hack, Franziska Maria. 2009. The particle $p a$ in the Dolomitic Ladin varieties of RhaetoRomance: diachronic evolution and synchronic variation. Paper presented at the XXXVIIth Romance Linguistics Seminar, January 5, 2009, University of Cambridge. Hand-out, 4 pages.

Haspelmath, Martin, 2006. Against markedness (and what to replace it with). Journal of Linguistics 42:11, 25-70.

Hirschbühler, Paul and Marie Labelle, 1997. La syntaxe de position dans les infinitivales négatives en moyen français. Bernard Combettes et Simone Monsonégo (Eds). Le moyen français. Philologie et linguistique; approches du texte et du discours. Actes du VIIIe Colloque international sur le moyen français. Paris: Didier Érudition. 483-506.

Hirschbühler, Paul and Marie Labelle, 1994a. Changes in verb position in French negative infinitival clauses. Language Variation and Change 6, 2, 149-178.

Hirschbühler, Paul and Marie Labelle, 1994b. L'évolution des proposition négatives infinitives en français. Pierre Attal (Ed.). La Négation : Actes du colloque de Paris X Nanterre, 12-13-14 novembre 1992. Linx 29, 59-90.

Hoeksema, Jack. 2009. Jespersen recycled. Elly van Gelderen (Ed.). Cyclical Change. Amsterdam and Philadelphia: Benjamins. 
Hopper, Paul J. and Elizabeth C. Traugott, 2003. Grammaticalization. Cambridge: Cambridge University Press.

Horn, Laurence R., 1993. Economy and Redundancy in a Dualistic Model of Natural Language. S. Shore et M. Vilkuna (Eds.). SKY 1993: 1993 Yearbook of the Linguistic Association of Finland. 33-72.

Horn, Laurence R., 1989. A Natural History of Negation. Chicago: Chicago University Press. Horn, Laurence R., 1984. Toward a new taxonomy for pragmatic inference: Q-based and Rbased implicature. D. Schiffrin (Ed.). Meaning, Form and Use in Context (GURT '84). Washington: Georgetown University Press. 11-42.

Ingham, Richard, In press. The Persistence of Anglo-Norman 1230-1362: A Linguistic Perspective. J. Wogan-Browne (Ed.). Proceedings of French of England Conference, York, July 2007.

Israel, Michael, 1998. The Rhetoric of grammar: Scalar reasoning and polarity sensitivity. PhD Thesis, University of California, San Diego.

Jespersen, Otto, 1917. Negation in English and other languages. Copenhagen: A. F. Høst. Kadmon, Nirit and Fred Landman, 1993. Any. Linguistics and philosophy, 15 353-422.

Kawaguchi, Yuji, 2008. Particules négatives du français ne, pas, point et mie. Un aperçu historique. Luc Baronian and France Martineau (Eds). Le français : d'un continent à l'autre. Québec: Presses de l'Université Laval.

Kiparsky, Paul and Cleo Condoravdi, 2006. Tracking Jespersen’s Cycle. Mark Janse, Brian D. Joseph, and Angela Ralli (Eds). Proceedings of the 2nd International Conference of Modern Greek Dialects and Linguistic Theory. Patras: University of Patras. 172-197. Available at http://www.stanford.edu/ kiparsky/ 
Lahousse, Karen. In press. Nominal inversion and the categorisation of sentence-initial elements. Journal of French Language Studies. 31 pages.

Larrivée, Pierre, under evaluation. Positive Polarity Items, Negation, Activated Propositions. MS, Aston University. 22 pages.

Larrivée, Pierre, 2009. Is there a Jespersen cycle? MS, Aston University. 19 pages. To appear in Pierre Larrivée and Richard Ingham (Eds), The Evolution of Negation.

Larrivée, Pierre, 2005. Variation diachronique, variation synchronique et réseaux de polysémie : à propos de certaines régularités apparentes dans le changement sémantique. Verbum 25,4, 431-442.

Larrivée, Pierre, 2004. L'association négative : depuis la syntaxe jusqu'à l'interprétation. Genève : Droz.

Larrivée, Pierre, 1995. Ne, négation de propositions virtuelles. Revue romane, 30,1, 27-40.

Lucas, Christopher, 2007. Jespersen's Cycle in Arabic and Berber. Transactions of the Philological Society 105,3, 398-431.

Martin, Robert, 1972. La négation de virtualité en moyen-français. Romania 93, 20-49.

Martin, Robert, 1966. Le mot rien et ses concurrents en français. Paris: Klincksieck.

Martineau, France, 2008a. A Variationist Perspective on the Evolution of French Negation. Hand-out of the presentation to the seminar of the project Cycles of Grammaticalization, August 2 2008, Aston University. 11 pages.

Martineau, France, 2008b Ver l'Ouest: les variétés laurentiennes. MS, University of Ottawa. $39 \mathrm{pp}$.

Martineau, France, 1994. Movement of negative adverbs in French infinitival clauses. Journal of French Language Studies 4, 1, 55-73. 
Martineau, France and Marie-Thérèse Vinet. 2004. Microvariation in French negative markers: An Historical perspective. F. Roca and M. Batlori (Eds). Grammaticalization and Parametric Change. Oxford: Oxford University Press. 194-205.

Masayuki, Ohkado, 2005. On Grammaticalization of Negative Adverbs, with Special Reference to Jespersen's Cycle Recast. Yoko Iyeiri (Ed.). Aspects of English Negation. Benjamins.

Meder, Franz, 1891. "Pas", "mie", "point" im Altfranzösischen. PhD thesis, Marburg.

Meillet, Antoine, 1912. L'évolution des formes grammaticales. Scientia 12,6.

Meisenberg, Trudel, 2004. Questions de ne. MS, Université Paris-X. http://www.projetpfc.net/?u_act $=$ download\&dfile=PFC4_meisenburg.pdf

Mellet, S. 1992. L'aternance ne / non en latin classique. L'Information grammatical 55, 28-32. Meunier, André et Mary-Annick Morel, 1993. Pas et point en français classique (Molière). L'Information grammaticale 57, 25-30.

Möhren, Frankwalt, 1980. Le renforcement affectif de la négation par l'expression d'une valeur minimale en ancien français. Tubingen: Niemeyer.

Moignet, Gérard, 1965. L'opposition non - ne en ancien français. Travaux de linguistique et de littérature 3,1, 46-66.

Morel, Mary-Annick, 1994. Pas et ne ... pas en français oral. Cahiers de praxématique 23, 97 116.

Mosegaard Hansen, Maj-Britt and Jacqueline Visconti, 2007. On the diachrony of "reinforced" negation in French and Italian. MS, University of Manchester and University of Genoa. 25 pages. Published in 2009 in Corinne Rossari, Corina Cojocariu, Claudia Ricci and Adriana Spiridon (Eds). Grammaticalization and pragmatics: facts, approaches, theoretical issues. Bingley: Emerald. 137-171. 
Offord, Malcom H., 1976. Negation in Berinus. A Contribution to the Study of Negation in Fourteenth Century French. Zeitschrift fur romanische Pbilologie 92, 3-4, 313-385.

Ohkado, Masayuki. 2005. On Grammaticalization of Negative Adverbs, with Special Reference to Jespersen's Cycle Recast. Yoko Iyeiri (Ed.). Aspects of English Negation, Amsterdam: Benjamins. 39-58.

Orlandini, Anna, 2001. Négation et argumentation en latin. Louvain: Peeters.

Parry, Mair. 1997. Clitic ordering in the dialects of the Ligurian-Piedmontese border, with particular reference to the preverbal negative. Zeitschrift für romanische Philologie 113, 243-71.

Pearce, Elizabeth, 1993. Diachronic change and negation in French. Rivista di Linguistica 5, $301-328$.

Pearce, Elizabeth, 1991. Tense and negation: Competing analyses in Middle French. Papers from the Regional Meetings, Chicago Linguistic Society 27,2, 218-232.

Pearce, Elizabeth, 1990. An Analysis of negated infinitives in Middle French. Wellington Working Papers in Linguistics 2, 31-45.

Perle, Friedrich, 1878. Die Negation im Altfranzösischen. Zeitschrift für romanische Philologie 2, 1-24 and 407-418.

Pouder, Marie-Christine. 2008. De l'oral de la conférence à l'écrit de l'article : figures de la négation dans un genre de vulgarisation du savoir encyclopédique. MS, Paris X. 21 pages. Price, Glanville, 1997. Negative particles in French. Stewart Gregory et David A. Trotter (Eds). De mot en mot: Aspects of medieval linguistics. Essays in honor of William Rothwell. Cardiff: University of Wales Press. 173-190.

Price, Glanville, 1993. Pas (point) without ne in interrogative clauses. Journal of French Language Studies 3,2, 191-195. 
Price, Glanville, 1962a. The Negative particles pas, mie and point in French. Archivum linguisticum 20-34.

Queffélec, Ambroise, 1990. Coordonnants actuels et coordonnant virtuel en ancien français. Revue québécoise de linguistique 19,1, 57-76.

Queffélec, Ambroise, 1985. La négation en ancien français. Thèse de doctorat d'État, Université de Paris IV.

Queffélec, Ambroise, 1984. La négation "explétive” en ancien français. Une approche psycho-mécanique. Bulletin du Centre de Romanistique et de Latinité Tardive de l’Université de Nice 2, 21-43.

Queffélec, Ambroise, 1989. La négation et l'exception dans Yvain. L’Information grammaticale 41, 22-27.

Reid, T. B. W., 1939. Non, nen and ne with finite verbs in French. Studies in French Language and Mediaeval Literature: Presented to Professor Mildred K. Pope by pupils, colleagues and friends. Manchester: Manchester University Press. 305-313.

Rowlett, Paul. 1998. Sentential negation in French. Oxford University Press.

Sankoff, Gillian and Diane Vincent. 1977. L'emploi productif de ne dans le français parlé à Montréal. Le français moderne 45, 243, 256.

Schøsler, Lene, 2008. Manuscrits du Charroi de Nimes. Hand-out of the presentation to the seminar of the project Cycles of Grammaticalization, August 2 2008, Aston University. 8 pages. Available at http:/ / www1.aston.ac.uk/EasySiteWeb/GatewayLink.aspx?alId=15323

Schwegler, Arnin, 1983. Predicate negation and word-order change. Lingua 61, 297-334. 
Schwenter, Scott A., 2006. Fine-tuning Jespersen's cycle. Betty J. Birner and Gregory Ward (Eds). Drawing the boundaries of meaning. Neo-Gricean studies in honour of Laurence R. Horn. Amsterdam and Philadelphia: Benjamins. 327-344.

Schwenter, Scott A., 2005. The Pragmatics of negation in Brazilian Portuguese. Lingua 115, 1427-1456.)

Stauf, Ida, 1927. Recherches sur ne redondant $\left(\mathrm{IX}^{\mathrm{e}}-\mathrm{XVII}{ }^{\mathrm{e}}\right.$ s.). Paris: Rousseau.

Taylor, Robert, 1976. Les préfixes de négation non et nient en ancien français. Actes du $13 e$ Congrès international de linguistique et de philologie romanes. Paris: Klincksieck. 647-658.

Tottie, Gunnel, 1991. Negation in English speech and writing: A study in variation. New York: Academic Press.

Traugott, Elisabeth Closs. 2003. From Subjectification to Intersubjectification. R. Hickey (Ed.), Motives for Language Change. Cambridge: Cambridge University Press. 124-139.

van Compernolle, Rémi A., 2009, Emphatic ne in informal spoken French and implications for foreign language pedagogy. International Journal of Applied Linguistics, 19, 1, 47-65.

van Compernolle, Rémi A., Williams, L. (Forthcoming). Variable omission of ne in real-time French chat: A corpus-driven comparison of educational and non-educational contexts. Canadian Modern Language Review.

van der Auwera, Johan, 2008. The Jespersen Cycles. MS, University of Antwerp. 30 pages. Völker, Harald, 2007. A 'practice of the variant' and the origins of the standard. Presentation of a variationist linguistics method for a corpus of Old French charters. Journal of French Language Studies, 17, 207-223.

Yvon, Henri, 1960a. Les expressions négatives dans la Vie de Saint-Louis de Joinville. Romania 81, 99-111. 
Yvon, Henri, 1960b. Les expressions négatives dans la Conqueste de Constantinople de Villehardouin. Romania 81, 269-307.

Yvon, Henri, 1959. Les expressions négatives dans la Queste del Saint Graal. Romania 80, 6378.

Yvon, Henri, 1948. Pas, point dans les propositions négatives. Le Français moderne 16, 19-35. 